\title{
Simultaneous Adsorptive Cathodic Stripping Voltammetric Determination of Nickel(II) and Cobalt(II) at an In Situ Bismuth- Modified Gold Electrode
}

\author{
A. Mardegan ${ }^{\dagger \mathrm{a}, \mathrm{b}, \mathrm{d}}$ S. Dal Borgo ${ }^{\dagger \mathrm{c}}$ P. Scopece, ${ }^{* \mathrm{~b}, \mathrm{~d}}$ L. M. Moretto, ${ }^{\mathrm{a}}$ S. B. Hočevar ${ }^{\mathrm{c}}$ P. Ugo ${ }^{\mathrm{a}}$ \\ a Department of Molecular Sciences and Nanosystems, University Ca' Foscari of Venice, S. Marta 2137, Venice, Italy \\ b CIVEN, Via delle Industrie 5, 30175, Venice-Marghera, Italy \\ c Analytical Chemistry Laboratory, National Institute of Chemistry, Hajdrihova 19, SI-1000 Ljubljana, Slovenia \\ d Present address: Veneto Nanotech, Via delle Industrie 5, 30175, Venice-Marghera, Italy \\ $\dagger$ A. Mardegan and S. Dal Borgo contributed equally to this work \\ *e-mail: paolo.scopece@venetonanotech.it
}

Received: July 5, 2013

Accepted: August 30, 2013

Published online: October 2, 2013

\begin{abstract}
A study on the simultaneous determination of $\mathrm{Ni}(\mathrm{II})$ and $\mathrm{Co}(\mathrm{II})$ dimethylglyoximates (Ni-DMG and Co-DMG) through adsorptive cathodic stripping voltammetry at an in situ bismuth-modified gold electrode (Bi-AuE) is reported. The key operational parameters, such as $\mathrm{Bi}(\mathrm{III})$ concentration, accumulation potential and accumulation time were optimized and the morphology of the Bi-microcrystals deposited on the Au-electrode was studied. The BiAuE allowed convenient analysis of trace concentrations of solely $\mathrm{Ni}(\mathrm{II})$ or of $\mathrm{Ni}$ (II) and $\mathrm{Co}(\mathrm{II})$ together, with cathodic stripping voltammograms characterized by well-separated stripping peaks. The calculated limit of detection $(L O D)$ was $40 \mathrm{ng} \mathrm{L}^{-1}$ for $\mathrm{Ni}(\mathrm{II})$ alone, whereas the $L O D$ was $98 \mathrm{ng} \mathrm{L}^{-1}$ for $\mathrm{Ni}(\mathrm{II})$ and $58 \mathrm{ngL}^{-1}$ for $\mathrm{Co}$ (II), when both metal ions were measured together. The optimized method was finally applied to the analysis of certified spring water (NIST1640a) and of natural water sampled in the Lagoon of Venice. The results obtained with the Bi$\mathrm{AuE}$ were in satisfactory agreement with the certified values and with those provided by complementary techniques, i.e., ICP-OES and ICP-MS.
\end{abstract}

Keywords: Bismuth film electrode, Gold electrode, Nickel, Cobalt, Cathodic adsorptive stripping voltammetry, Water analysis

DOI: 10.1002/elan.201300320

\section{Introduction}

The power and scope of electrochemical stripping analysis have been greatly enhanced during the past decades owing to the introduction of novel electrode materials and associated procedures [1]. The unique accumulation of metal analytes relies on the efficient formation of amalgams/alloys in/on the surface of the working electrode. When the analyte reacts irreversibly or forms intermetallic compounds or cannot form an amalgam/alloy, adsorptive stripping protocols can be an interesting approach $[2,3]$. Adsorptive stripping procedures commonly rely on the interfacial accumulation of target metal complexes onto a mercury drop or mercury film electrode, thus a large variety of metal analytes such as vanadium [4], chromium [5,6], molybdenum [7], aluminum [8], nickel and cobalt [9], etc. can be successfully determined. Despite mercury's attractive electroanalytical performance, there is a growing demand to replace mercury with alternative, nontoxic and "environmentally friendly" electrode materials.
Thus, numerous electrode materials, e.g. silver [10], iridium [11], several alloys [12] and different configurations of carbon [13] were used as an alternative to mercury analogues, but none of them approached the excellent electroanalytical performances of $\mathrm{Hg}$. A bismuth film electrode (BiFE) was for the first time proposed by J. Wang et al. in 2000 [14]. Due to its non-toxic character, wide operational potential window and even improved performance in the presence of dissolved oxygen, bismuth has been accepted as an efficient replacement for mercury, and has been used in numerous electroanalytical laboratories worldwide.

Electrochemical methods for measuring nickel(II) and cobalt(II) with bismuth-modified electrodes have been proposed in the last decade $[15,16]$. The majority of these studies were performed using an ex situ prepared bismuth film electrode with bismuth deposited usually onto different carbon substrates [17-19], while Alves et al. proposed a solid bismuth vibrating electrode for the determination of $\mathrm{Ni}(\mathrm{II})$ and $\mathrm{Co}(\mathrm{II})$ [20]. 
Only few papers report on the application of bismuthmodified gold electrodes for anodic (or adsorptive/cathodic) stripping voltammetry/potentiometry [21-26].

With the goal of developing electrodes suitable for multiple analysis of water pollutants, we focus here on gold substrate as a widespread material which display valuable performances both for the anodic stripping analysis of toxic copper(II) ions such as arsenic(III) [27-29], copper(II) [28] and mercury(II) [30] and for the cathodic stripping determination of other water pollutants such as nickel(II) and cobalt(II). In principle, the same gold substrate could be used as a bare electrode for the anodic determination of the first three above analytes, while after the modification of Au with bismuth, one could perform the simultaneous determination also of $\mathrm{Ni}(\mathrm{II})$ and $\mathrm{Co}(\mathrm{II})$.

Recently, M. Korolczuk et al. [31,32], and Sopha et al. [33] proposed the use of in situ prepared BiFE and antimony film electrode (SbFE) for measuring solely nickel ions. The only example of simultaneous determination of nickel and cobalt was reported by Korolczuk et al. using an in situ prepared lead film electrode (PbFE) [34], but lead is also a toxic element.

The above considerations prompted us to study and apply to water analyses an electrochemical method suitable for the simultaneous determination of nickel(II) and cobalt(II), using an in situ prepared bismuth-modified gold electrode (Bi-AuE) as a substitute for the $\mathrm{Hg}$ electrode used previously for similar purposes [35]. Compared to the ex situ preparation procedure, the proposed in situ strategy should require simpler and faster operativity, while furnishing sensitive and reliable analytical results since a fresh electrode surface is used for each measurement. This protocol also obviates the need of using bromide, which has been proposed as an additive suitable to stabilize the ex situ prepared bismuth film [36].

The very sensitive method developed was successfully validated also in real samples, namely water samples from the lagoon of Venice, by comparing the results obtained electrochemically with the Bi-AuE with those obtained by ICP-MS and ICP-OES analyses, which require more costly instrumentation and are not suitable for direct onfield testing or decentralized monitoring.

\section{Experimental}

\subsection{Reagents and Materials}

The working electrode was a conventional Au-disc electrode embedded in Teflon with a geometric area of $0.07 \mathrm{~cm}^{2}$. Standard solutions of $\mathrm{Bi}(\mathrm{III}), \mathrm{Ni}(\mathrm{II})$ and $\mathrm{Co}(\mathrm{II})$ (1000 $\left.\mathrm{mg} \mathrm{L}^{-1}\right)$ were provided by Merck and diluted as required with $0.01 \mathrm{molL}^{-1} \mathrm{HCl}$. Other standard solutions (ICP-MS standards of $\mathrm{Zn}(\mathrm{II}), \mathrm{Al}(\mathrm{III}), \mathrm{Cr}(\mathrm{III}), \mathrm{Fe}(\mathrm{III})$, $\mathrm{Cu}(\mathrm{II}))$ were also purchased from Merck and diluted with $\mathrm{HCl}$ to $\mathrm{pH}$ 2. $0.1 \mathrm{molL}^{-1}$ ammonia buffer ( $\mathrm{pH} 9.0$ ) was prepared from analytical grade reagents, Sigma Aldrich. $1 \mathrm{molL}^{-1}$ potassium sodium tartrate and $0.01 \mathrm{molL}^{-1}$ di- methylglyoxyme (DMG) were prepared from the reagents obtained from Sigma.

NIST 1640a certified reference standard was provided by the National Institute of Standards \& Technology of the United States. It consists of spring water acidified with $2 \% \mathrm{HNO}_{3}$ with mass fractions and mass concentrations assigned for 22 elements. The certified concentration of $\mathrm{Ni}$ (II) is $27.4 \pm 0.8 \mu \mathrm{g} \mathrm{L}^{-1}$ and of $\mathrm{Co}$ (II) is $20.1 \pm$ $0.3 \mu \mathrm{g} \mathrm{L}{ }^{-1}$.

\subsection{Apparatus}

All adsorptive cathodic stripping voltammetric (AdCSV) measurements were carried out using a CHI440 electrochemical workstation at room temperature $\left(22^{\circ} \mathrm{C}\right)$. A classical $20 \mathrm{~mL} 3$-electrodes single compartment electrochemical cell equipped with a bismuth-modified gold electrode as the working electrode, a platinum wire as the counter electrode and an $\mathrm{Ag} / \mathrm{AgCl}$ ( $\mathrm{KCl}$ sat.) reference electrode was used. The gold electrode was polished daily using $0.3 \mu \mathrm{m}$ alumina slurry. Morphological information of the electrode surface was achieved with a VEGA TS 5130 LM (Tescan) Scanning Electron Microscope. Real sample investigations were carried out using a quadrupole ICP-MS instrument Agilent 7500ce (Agilent Technologies) and an Optima 2100 DV (Perkin Elmer) ICP-OES.

\subsection{Procedures}

The working electrode was dipped into a $0.1 \mathrm{~mol} \mathrm{~L}^{-1}$ ammonium buffer solution containing $10 \mathrm{mgL}^{-1} \mathrm{Bi}(\mathrm{III})$ in the form of its complex with tartrate and $1 \times 10^{-5} \mathrm{molL}^{-1}$ DMG as complexing agent. Tartrate was selected in order to avoid the precipitation of bismuth at the $\mathrm{pH}$ value necessary for $\mathrm{Ni}(\mathrm{II})$ and $\mathrm{Co}(\mathrm{II})$ determination [32]. A twostep accumulation protocol, i.e. (i) $-1.1 \mathrm{~V}$ for $60 \mathrm{~s}$ (in situ deposition of bismuth) followed by (ii) $-0.8 \mathrm{~V}$ for $120 \mathrm{~s}$ (accumulation of Ni-DMG and/or Co-DMG complexes), was applied under stirring conditions. After the accumulation step, stirring was stopped and following a 15 s equilibration period, a stripping square-wave voltammogram was recorded from $-0.8 \mathrm{~V}$ to $-1.3 \mathrm{~V}$, with a frequency of $25 \mathrm{~Hz}$, a potential step of $5 \mathrm{mV}$ and amplitude of $50 \mathrm{mV}$. After each measurement a cleaning step was applied by holding the potential at $+0.3 \mathrm{~V}$ for $60 \mathrm{~s}$.

\section{Results and Discussion}

\subsection{Morphological Characterization of the In Situ Prepared Bismuth-Modified Gold Electrode}

Aimed at obtaining insights into the morphology of bismuth deposits on a gold substrate, scanning electron microscopy (SEM) studies were carried out before and after the electrochemical deposition of bismuth. Figures $1 \mathrm{~A}$ and $1 \mathrm{~B}$ show SEM images of a bare gold electrode surface after its immersion for 5 minutes in $0.1 \mathrm{molL}^{-1}$ ammonium buffer solution containing $0.01 \mathrm{molL}^{-1}$ tartrate 
ions. The star-like structures visible on the gold electrode surface with a regular distribution are consistent with tartrate crystals, as confirmed also by the literature [37]. Figures $1 \mathrm{C}$ and $1 \mathrm{D}$ show the same gold electrode surface after $60 \mathrm{~s}$ of electrochemical deposition of bismuth at $-1.1 \mathrm{~V}$ from a $0.1 \mathrm{molL}^{-1}$ ammonium buffer solution containing $0.01 \mathrm{molL}^{-1}$ tartrate and $10 \mathrm{mgL}^{-1} \mathrm{Bi}$ (III). The images clearly depict the formation of bismuth microcrystals aggregated in rosettes indicating that these microcrystals are formed on the surface of the gold electrode instead of a bulk deposit. These results are similar to those obtained with a deposition from an acidic solution using carbon substrate $[38,39]$. Note that the structure of the tartrate crystals is still detectable in Figures 1C and 1D, although with a lower contrast.

\subsection{Optimization of the Experimental Procedure}

As proposed by F. Ma et al. [40], the mechanism for the adsorption and cathodic stripping voltammetry of $\mathrm{M}(\mathrm{II})$ $\mathrm{DMG}_{2}(\mathrm{M}(\mathrm{II})$ is either $\mathrm{Ni}(\mathrm{II})$ or $\mathrm{Co}(\mathrm{II})$ ) complexes can be explained as:

$\mathrm{M}(\mathrm{II})-\mathrm{DMG}_{2}$ (solution) $\rightarrow \mathrm{M}(\mathrm{II})-\mathrm{DMG}_{2}$ (ads)

After adsorption on the electrode surface the application of cathodic potential scan results in the reduction of the metal complex represented by the equation:

$\mathrm{M}(\mathrm{II})-\mathrm{DMG}_{2}(\mathrm{ads})+\mathrm{ne}^{-} \rightarrow \mathrm{M}(\mathrm{II})-\mathrm{DMG}_{2}{ }^{n-}$
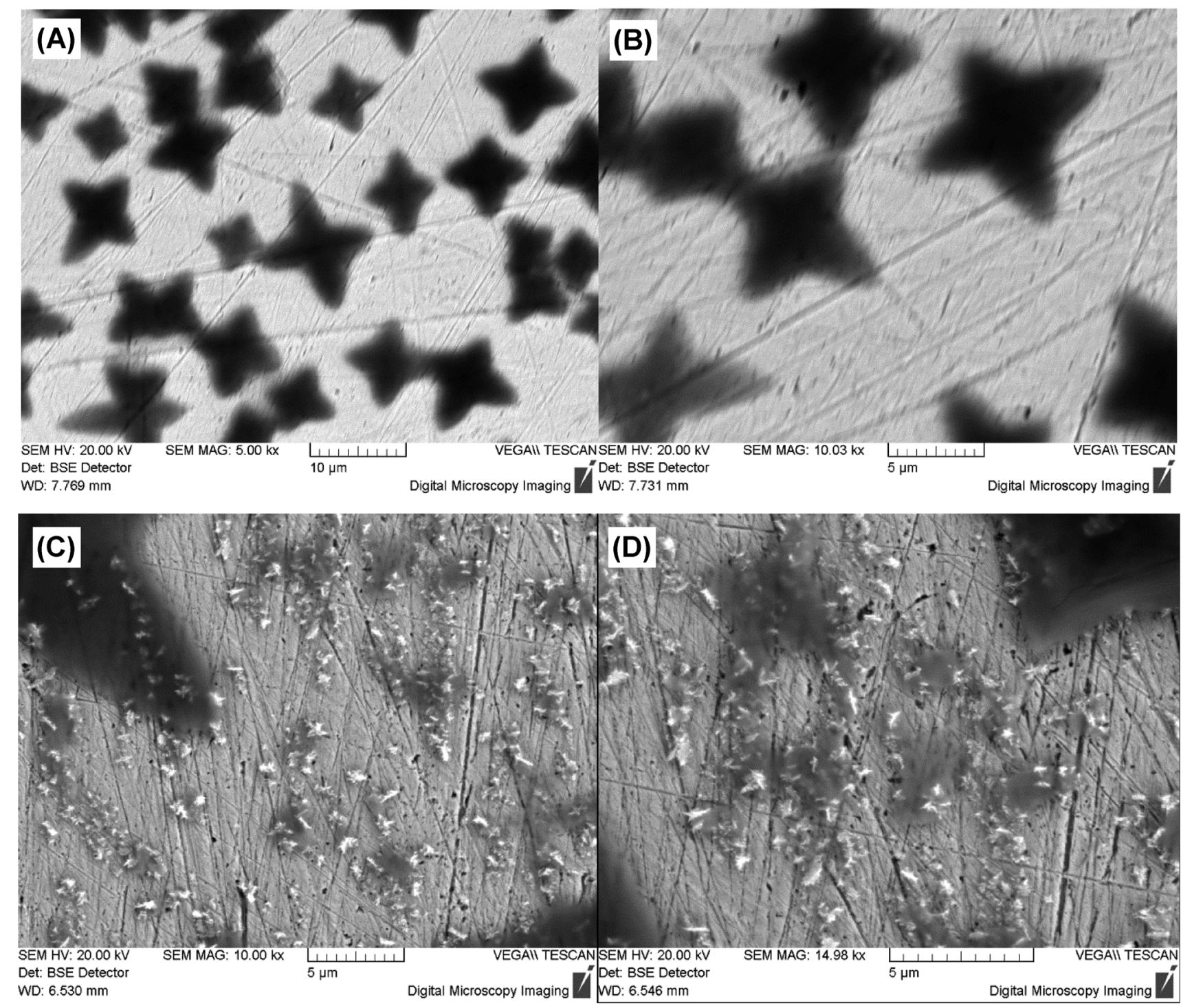

Fig. 1. A and B) SEM images of the gold electrode surface after 5 minutes dipping in a $0.1 \mathrm{molL}^{-1}$ ammonium buffer solution containing $0.01 \mathrm{~mol} \mathrm{~L}^{-1}$ tartrate. $\mathrm{C}$ and $\mathrm{D}$ ) the same gold electrode surface after $60 \mathrm{~s}$ of electrochemical deposition of bismuth at $-1.1 \mathrm{~V}$ from the same solution containing also $10 \mathrm{mg} \mathrm{L}^{-1} \mathrm{Bi}(\mathrm{III})$. 
In Reaction 2, the metal ion, the ligand, or both are reduced. The first step is the reduction of the central metal ion:

$\mathrm{M}(\mathrm{II})-\mathrm{DMG}_{2}($ ads $)+2 \mathrm{e}^{-} \rightarrow \mathrm{M}(0)+2 \mathrm{DMG}^{-}($ads $)$

followed by a four electron reduction of the glyoximate ligand:<smiles>CC#C[C@H](C)C(C)N(O)O</smiles>

The resulting reduction peak, which describes both the cathodic Reactions 3 and 4, is a result of a 10 electron transfer, i.e. 2 for the metal ion and 4 for each of the two ligands [40]. The typical AdCSV for the Ni-complex obtained at Bi-AuE is shown in Figure 2.

To optimize the electroanalytical performance of the proposed sensor, the operational parameters such as the in situ bismuth deposition (the first step), the accumulation time (the second step) and the accumulation potential (the second step), were examined. The optimization of the first step was carried out at fixed deposition time of $60 \mathrm{~s}$ and deposition potential of $-1.1 \mathrm{~V}$. During this step Bi was deposited on the gold electrode surface, whereas Ni(II)-DMG complex, which was also present in the solution, was not adsorbed, since the adsorption

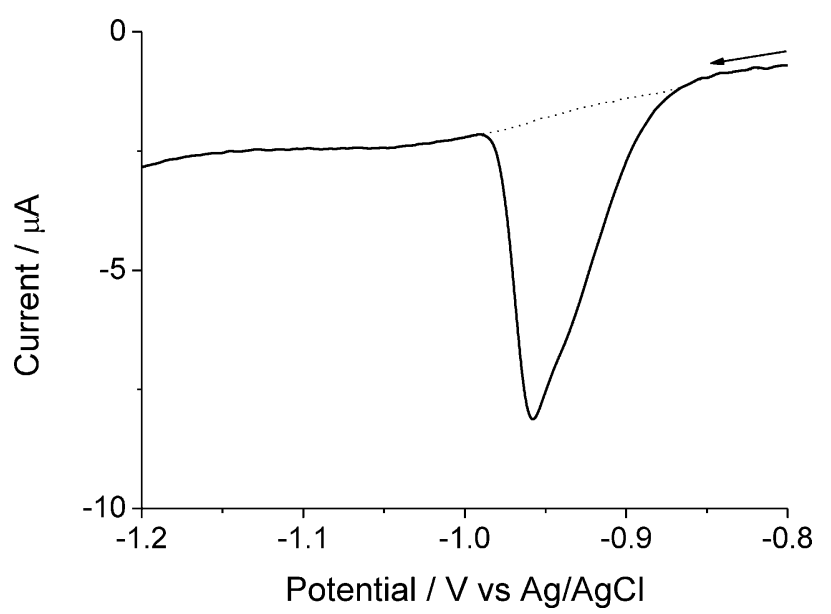

Fig. 2. AdCSV of the in situ prepared $\mathrm{Bi}-\mathrm{AuE}$ in $0.1 \mathrm{molL}^{-1}$ ammonia buffer solution (pH 9.0) containing $10 \mathrm{mgL}^{-1} \mathrm{Bi}(\mathrm{III})$, $1 \times 10^{-5} \mathrm{molL}^{-1} \mathrm{DMG}$ and $0.01 \mathrm{~mol} \mathrm{~L}^{-1}$ potassium sodium tartrate. Deposition at $-1.1 \mathrm{~V}$ for $60 \mathrm{~s}$ followed by accumulation at $-0.8 \mathrm{~V}$ for $60 \mathrm{~s}$; equilibration time of $15 \mathrm{~s}$; SWV parameters: frequency of $25 \mathrm{~Hz}$, potential step of $5 \mathrm{mV}$ and amplitude of $50 \mathrm{mV}$. Solid line refers to AdCSV recorded in a solution containing $50 \mu \mathrm{gL}^{-1} \mathrm{Ni}(\mathrm{II})$, dotted line refers to AdCSV in the absence of $\mathrm{Ni}(\mathrm{II})$.

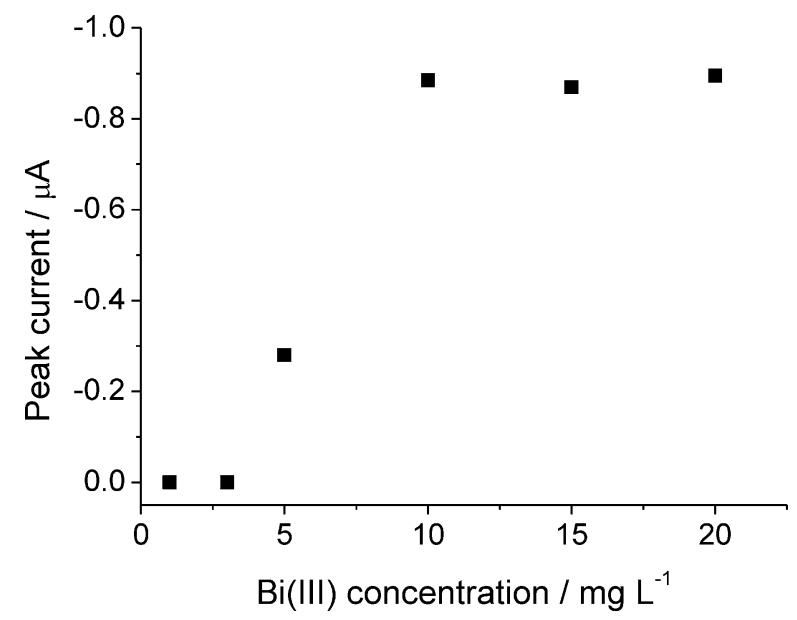

Fig. 3. Effect of $\mathrm{Bi}(\mathrm{III})$ concentration on the $\mathrm{Ni}(\mathrm{II})$ stripping peak current. Concentration of $\mathrm{Ni}(\mathrm{II}) 5 \mu \mathrm{g} \mathrm{L}^{-1}$. Other conditions as in Figure 2.

occurs at potentials between ca. -0.8 and $-0.6 \mathrm{~V}$ and the adsorbed complex is reduced at ca. $-0.95 \mathrm{~V}$. The concentration of $\mathrm{Bi}(\mathrm{III})$ in the measurement solution was changed in the range of 1 to $20 \mathrm{mgL}^{-1}$, and its effect upon the $\mathrm{Ni}(\mathrm{II})$ stripping signal is shown in Figure 3. Evidently, the stripping peak current increased by increasing the concentration of $\mathrm{Bi}(\mathrm{III})$ from $5 \mathrm{mgL}^{-1}$ and reached a constant value when the $\mathrm{Bi}(\mathrm{III})$ concentration was $\geq 10 \mathrm{mg} \mathrm{L}^{-1}$. The increase of the signal can be attributed to the higher bismuth film surface area accessible for electrochemical adsorption of Ni(II)-DMG complex, until reaching a plateau, which indicates the achievement of the maximum surface coverage by the adsorbed nickel complex. It is important to note that at $\mathrm{Bi}(\mathrm{III})$ concentrations lower than $5 \mathrm{mgL}^{-1}$ no $\mathrm{Ni}$ (II) signal was recorded; this fact can be explained also by considering the enhanced hydrogen evolution reaction at the surface of a gold substrate electrode. Indeed, it has been already demonstrated that the hydrogen evolution contributes to a large increase of the background current in the case of gold electrodes at potential values more negative than $-0.6 \mathrm{~V}$ [23]. Finally, by performing 20 independent determinations with $\mathrm{Bi}(\mathrm{III})$ concentrations of 10,15 , and $20 \mathrm{mg} \mathrm{L}^{-1}$, the relative standard deviation $(R S D)$ values were $2.2,5.5$ and $6.0 \%$, respectively. This prompted us to use $10 \mathrm{mg} \mathrm{L}^{-1} \mathrm{Bi}(\mathrm{III})$, as the most suitable concentration in all further experiments.

Figure 4 shows the effect of the accumulation potential of Ni-DMG complex upon the Ni(II) stripping peak in the examined potential range of -0.5 to $-0.85 \mathrm{~V}$. It is evident that the highest signal was observed between -0.7 and $-0.8 \mathrm{~V}$, and at more negative accumulation potentials the signal decreased due to the beginning of the reduction of Ni(II)-DMG complex. Thus, for further studies the accumulation potential of $-0.8 \mathrm{~V}$ was chosen.

Figure 5 depicts the dependence of the Ni(II) stripping peak current upon the accumulation time for two concentrations of $\mathrm{Ni}(\mathrm{II})$, i.e. for $5 \mu \mathrm{gL}^{-1}$ (full circles) and for 


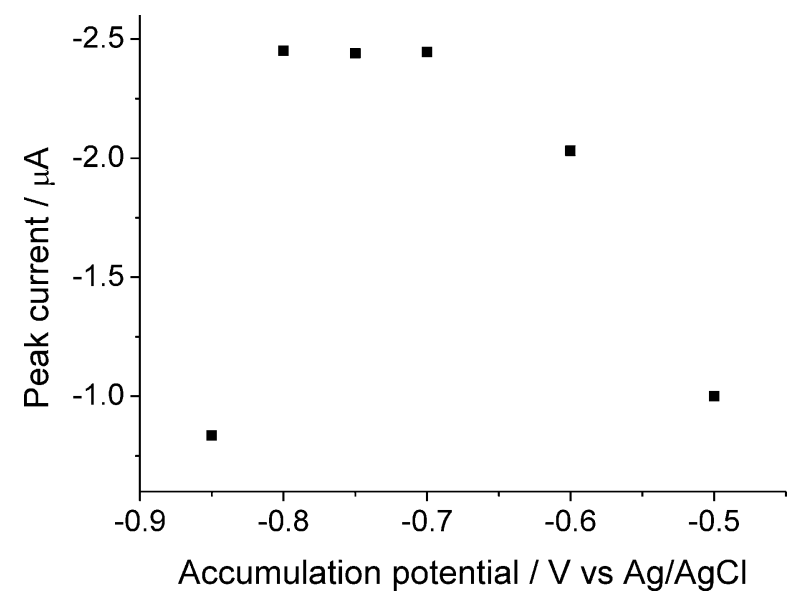

Fig. 4. Effect of the accumulation potential on the Ni(II) stripping peak current. Concentration of $\mathrm{Ni}(\mathrm{II})$ and $\mathrm{Bi}(\mathrm{III}) 10 \mu \mathrm{g} \mathrm{L}^{-1}$ and $10 \mathrm{mg} \mathrm{L}^{-1}$, respectively; accumulation time $60 \mathrm{~s}$. Other conditions as in Figure 2.

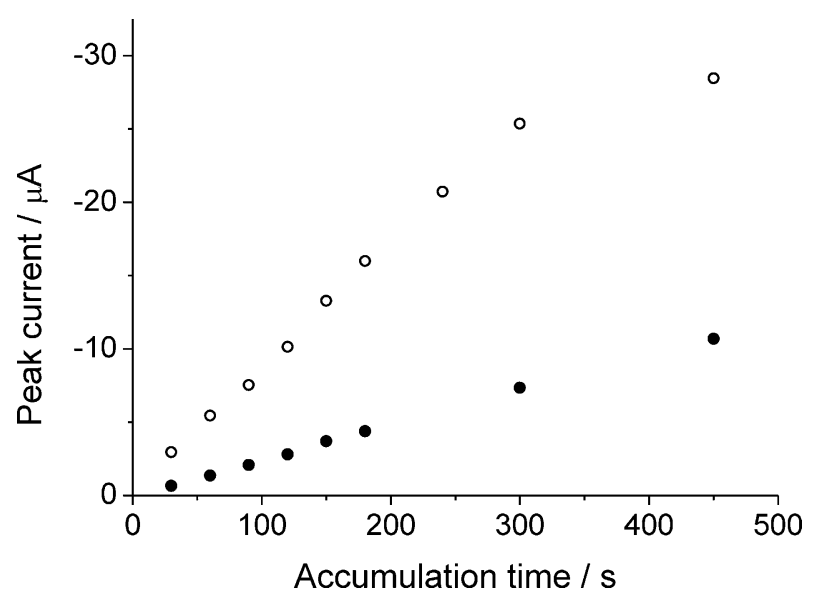

Fig. 5. Effect of the accumulation time on the Ni(II) stripping peak current. Concentration of $\mathrm{Ni}(\mathrm{II}) 5 \mu \mathrm{g} \mathrm{L}^{-1}$ (full circles) and $50 \mu \mathrm{gL}^{-1}$ (hollow circles); concentration of $\mathrm{Bi}(\mathrm{III}): 10 \mathrm{mgL}^{-1}$. Other conditions as in Figure 2.

$50 \mu \mathrm{gL}^{-1}$ (hollow circles) in the range of 30 to $450 \mathrm{~s}$. In the case of $5 \mu \mathrm{gL}^{-1}$ the signal increased linearly with the accumulation time and no saturation effect was observed. On the other hand, when $\mathrm{Ni}$ (II) concentration was $50 \mu \mathrm{gL}^{-1}$ the stripping signal increased linearly up to $300 \mathrm{~s}$ and then leveled off. Accordingly, an accumulation time of $120 \mathrm{~s}$ was selected as the optimal compromise between high sensitivity and short analysis time. However, for measuring more concentrated samples it is obvious that shorter accumulation times should be used.

\subsection{Calibration}

The electroanalytical performance of the bismuth-modified gold electrode was further studied by increasing the concentration of $\mathrm{Ni}(\mathrm{II})$ in the range of 0.5 to $15.0 \mu \mathrm{g} \mathrm{L}^{-1}$, as shown in Figure 6 and in corresponding inset. The electrode showed a favourable linear behavior in the exam-

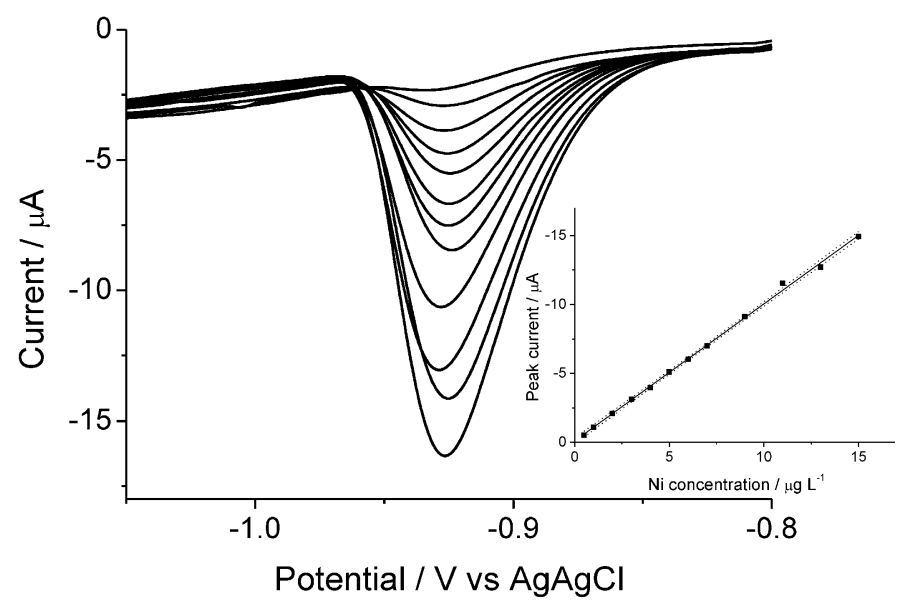

Fig. 6. AdCSVs at the in situ prepared Bi-AuE for increasing concentrations of $\mathrm{Ni}(\mathrm{II})$ in the range of $0.5-15 \mu \mathrm{gL}^{-1}$ in $0.1 \mathrm{molL}^{-1}$ ammonia buffer solution ( $\left.\mathrm{pH} 9.0\right)$ containing $10 \mathrm{mg} \mathrm{L}^{-1} \mathrm{Bi}(\mathrm{III}), 1 \times 10^{-5} \mathrm{~mol} \mathrm{~L}^{-1} \mathrm{DMG}$ and $0.01 \mathrm{~mol} \mathrm{~L}^{-1}$ potassium sodium tartrate. Deposition at $-1.1 \mathrm{~V}$ for $60 \mathrm{~s}$ followed by accumulation at $-0.8 \mathrm{~V}$ for $120 \mathrm{~s}$. Inset shows the corresponding calibration plot with $R^{2}$ of 0.998 and related confidence band $(95 \%)$. Other conditions as in Figure 2.

ined concentration range in combination with $120 \mathrm{~s}$ accumulation time. The limit of detection $(L O D)$ was calculated by using $3 \sigma / \mathrm{m}$ criterion; the $\sigma$ value was calculated with two methods: (i) by using the standard deviation of the calibration plot, and (ii) by the standard deviation of repeated measurements performed at low $\mathrm{Ni}$ (II) concentration, i.e. 10 measurements of $0.5 \mu \mathrm{g} \mathrm{L}{ }^{-1} \mathrm{Ni}$ (II) combined with $120 \mathrm{~s}$ accumulation time. In both cases a $L O D$ of $40 \mathrm{ng} \mathrm{L}^{-1}$ was achieved which is the lowest value compared with other electroanalytical methods reported in the literature [15-19]. This sensitivity, attributed also to a 10-electron transfer process [39], is associated with excellent repeatability with relative standard deviation $(R S D)$ of $2.2 \%$ based on 20 consecutive measurements of $0.5 \mu \mathrm{gL}^{-1} \mathrm{Ni}(\mathrm{II})$.

\subsection{Simultaneous Analysis of Ni and Co}

A common problem associated with the electrochemical measurement of $\mathrm{Ni}(\mathrm{II})$ is the partial overlap of the $\mathrm{Ni}(\mathrm{II})$ signal with that of $\mathrm{Co}(\mathrm{II})$, which is also complexed by DMG [14]. In the literature, several papers report on the analysis of $\mathrm{Ni}(\mathrm{II})$ with bismuth-based electrodes, but only few of them describe the simultaneous determination of both metal ions, i.e. Ni(II) and $\mathrm{Co}(\mathrm{II})[15,16]$. Figure 7 shows the AdCSVs recorded at the Bi-AuE in $0.1 \mathrm{~mol} \mathrm{~L}^{-1}$ ammonia buffer solution containing $0.01 \mathrm{molL}^{-1}$ sodium potassium tartrate, $10 \mathrm{mgL}^{-1} \mathrm{Bi}(\mathrm{III})$ and $1 \times 10^{-5} \mathrm{molL}^{-1}$ DMG for increasing amounts of $\mathrm{Ni}(\mathrm{II})$ and $\mathrm{Co}(\mathrm{II})$. As can be seen, the Bi-AuE unveils two well-resolved stripping peaks centered around $-0.94 \mathrm{~V}$ and $-1.03 \mathrm{~V}$ for $\mathrm{Ni}(\mathrm{II})$ and $\mathrm{Co}(\mathrm{II})$, respectively. The peak at $-0.94 \mathrm{~V}$ increased linearly for increasing the concentration of $\mathrm{Ni}$ (II) from 5 to $35 \mu \mathrm{gL}^{-1}$, whereas the peak at $-1.03 \mathrm{~V}$ scaled 


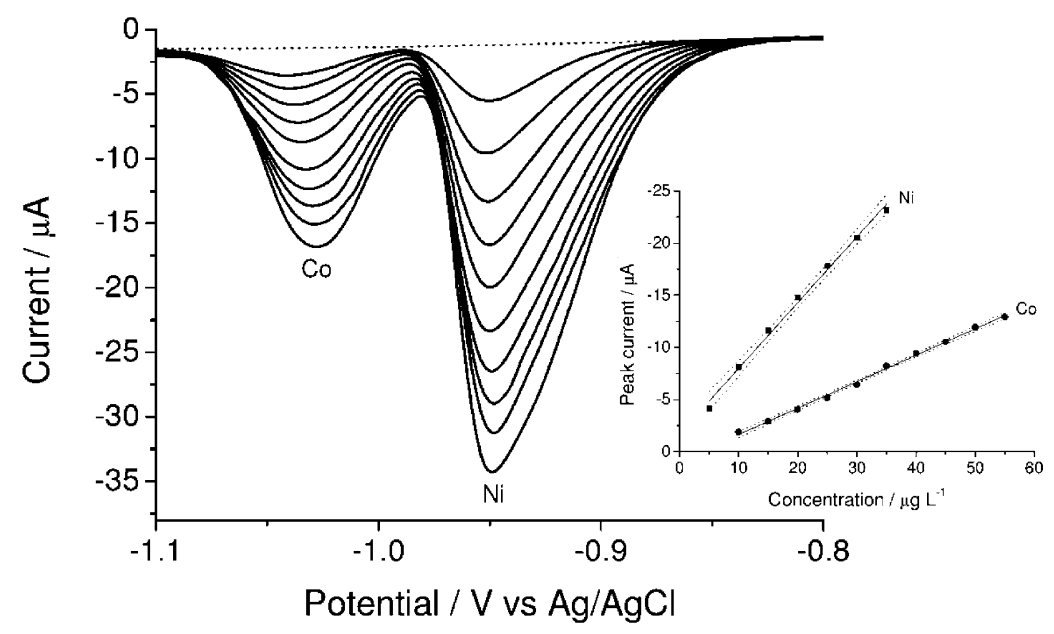

Fig. 7. AdCSVs obtained at the in situ prepared Bi-AuE for increasing concentrations of $\mathrm{Ni}(\mathrm{II})$ and $\mathrm{Co}(\mathrm{II})$. Deposition at $-1.1 \mathrm{~V}$ for $60 \mathrm{~s}$ followed by accumulation at $-0.8 \mathrm{~V}$ for $120 \mathrm{~s}$; ; equilibration time of $15 \mathrm{~s}$. Inset: corresponding calibration plots with $R^{2}$ of 0.989 for $\mathrm{Ni}(\mathrm{II})$ and $R^{2}$ of 0.997 for $\mathrm{Co}(\mathrm{II})$, and related confidence bands $(95 \%)$. Other conditions as in Figure 2.

with increasing the $\mathrm{Co}(\mathrm{II})$ concentration in the range of 10 to $55 \mu \mathrm{gL}^{-1}$ (see also corresponding inset). In this case, the calculated LODs $(3 \sigma / \mathrm{m})$ were 97 and $58 \mathrm{ngL}^{-1}$ for $\mathrm{Ni}(\mathrm{II})$ and $\mathrm{Co}(\mathrm{II})$, respectively. The analytical performances here obtained are compared in Table 1 with those reported in the literature with reference to bismuth electrodes prepared by using different procedures. Such a comparison highlights the excellent analytical characteristcs of the present method which combines the capability of achieving very low $L O D$ both for $\mathrm{Ni}$ and $\mathrm{Co}$, together with the easier applicability of the in situ modification procedure.

$\mathrm{Ni}$ (II) was readily measured also in a solution containing fixed amount of $\mathrm{Co}(\mathrm{II})$ as a possible interference. Figure 8 shows the AdCSVs recorded in solution spiked with increasing amounts of $\mathrm{Ni}(\mathrm{II})$, whereas the concentration of $\mathrm{Co}(\mathrm{II})$ was kept constant, i.e. $20 \mu \mathrm{gL}^{-1}$. The obtained AdCSVs indicate that $\mathrm{Co}(\mathrm{II})$ does not interfere with neighboring signal of $\mathrm{Ni}(\mathrm{II})$, thus it was possible to measure trace concentrations of $\mathrm{Ni}(\mathrm{II})$ also in the presence of a 20 fold excess of $\mathrm{Co}(\mathrm{II})$. In this case, the calculated $L O D$ for $\mathrm{Ni}(\mathrm{II})(3 \sigma / \mathrm{m})$ was $77 \mathrm{ngL}^{-1}$.

\subsection{Study of Interferences for Measuring Ni(II)}

The possible effect of selected metal ions in solution containing $4 \mu \mathrm{gL}^{-1} \mathrm{Ni}$ (II) in combination with $60 \mathrm{~s}$ accumulation time was studied and the influence upon the $\mathrm{Ni}(\mathrm{II})$ peak current is presented in Table 2. The results indicate that $\mathrm{Zn}$ and $\mathrm{Cr}$ excess cause negligible effects and that $\mathrm{Fe}, \mathrm{Al}$ and $\mathrm{Cu}$ cause an approximately $20 \%$ change in the $\mathrm{Ni}$ stripping current only when present in 500-fold excess. As far as $\mathrm{Co}(\mathrm{II})$ is concerned, a 10 fold excess is un-influent while a 50 -fold excess reflects in a $50 \%$ decrease in sensitivity. Note that the main reason behind this decrease in sensitivity for $\mathrm{Ni}(\mathrm{II})$ is related to a partial overlap of the two adsorptive stripping peaks; however, the quantitative determination of nickel can be anyhow performed by using the standard additions method. Finally, also the effect of the surfactant Triton-X on the Ni(II) stripping signal was examined; it was observed that the peak of $\mathrm{Ni}(\mathrm{II})$ decreased to $26 \%$ of its original value when $1 \mathrm{mgL}^{-1}$ of surfactant was present in the measurement solution.

Table 1. Adsorptive stripping voltammetric (AdSV) determination of $\mathrm{Ni}$ and Co at various bismuth electrodes with related $L O D$ and type of samples analyzed.

\begin{tabular}{|c|c|c|c|c|c|c|}
\hline Working electrode & $\begin{array}{l}\text { Surface modification } \\
\text { strategy }\end{array}$ & $\begin{array}{l}\operatorname{LOD~Ni(II)} \\
\left(\mu \mathrm{g} \mathrm{L}^{-1}\right)\end{array}$ & $\begin{array}{l}L O D \mathrm{Co}(\mathrm{II}) \\
\left(\mu \mathrm{g} \mathrm{L}^{-1}\right)\end{array}$ & $\begin{array}{l}\text { Deposition } \\
\text { time (s) }\end{array}$ & Type of samples & Reference \\
\hline $\begin{array}{l}\text { Solid bismuth vibrating } \\
\text { electrode }\end{array}$ & No modification & 0.6 & 1.0 & 30 & Certified surface water & {$[20]$} \\
\hline $\begin{array}{l}\text { BiF on GC microelec- } \\
\text { trode }\end{array}$ & $\begin{array}{l}\text { Ex situ with added } \\
\mathrm{NaBr}\end{array}$ & 0.06 & 0.07 & 60 & Body fluid samples & {$[15]$} \\
\hline $\begin{array}{l}\text { BiF on GC microelec- } \\
\text { trode }\end{array}$ & $\begin{array}{l}\text { Ex situ with added } \\
\mathrm{NaBr}\end{array}$ & 0.09 & 0.07 & 120 & No real samples & {$[36]$} \\
\hline $\begin{array}{l}\mathrm{BiF} \text { on rotating } \mathrm{GC} \text { elec- } \\
\text { trode }\end{array}$ & Ex situ & 0.1 & 0.07 & 300 & River water and iron ore & {$[41]$} \\
\hline BiF on GC electrode & Ex situ & 0.26 & 0.08 & 60 & No real samples & {$[16]$} \\
\hline $\begin{array}{l}\text { Bi microparticles on gold } \\
\text { electrode }\end{array}$ & In situ & 0.06 & 0.1 & 120 & $\begin{array}{l}\text { Certified spring water and } \\
\text { lagoon water }\end{array}$ & $\begin{array}{l}\text { Present } \\
\text { work }\end{array}$ \\
\hline
\end{tabular}




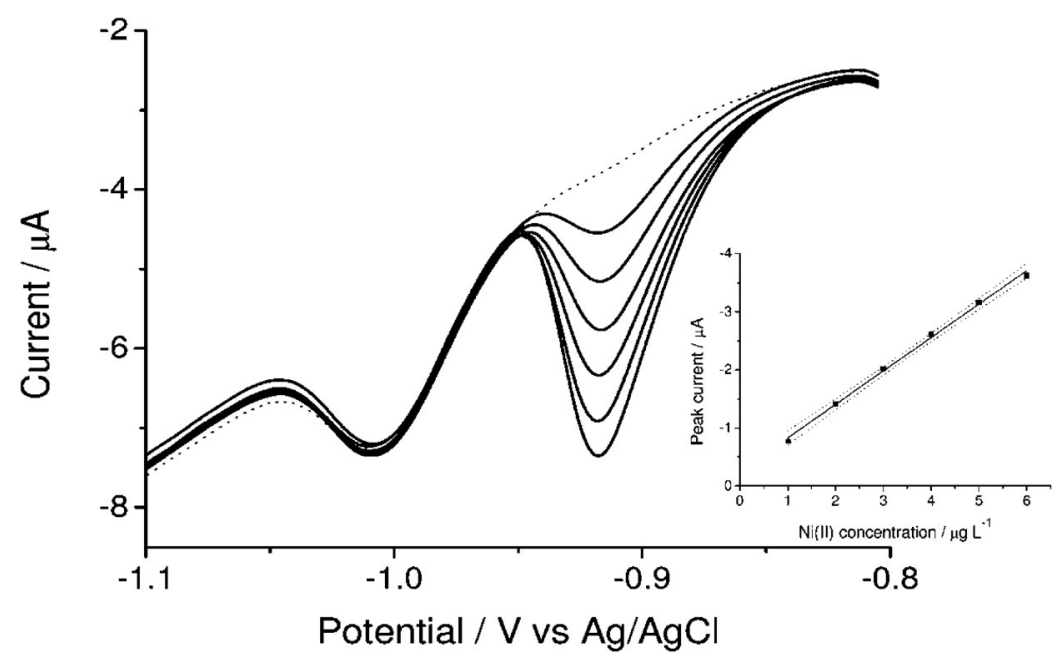

Fig. 8. AdCSVs obtained at the in situ prepared Bi-AuE for increasing concentrations of Ni(II) from 0 (dotted line) to $6 \mu \mathrm{g} \mathrm{L}^{-1}$ (full lines) in $0.1 \mathrm{molL}^{-1}$ ammonia buffer solution ( $\left.\mathrm{pH} 9.0\right)$ containing $0.01 \mathrm{molL}^{-1}$ sodium potassium tartrate, $1 \times 10^{-5} \mathrm{molL}^{-1} \mathrm{DMG}$, $10 \mathrm{mg} \mathrm{L}^{-1} \mathrm{Bi}(\mathrm{III})$, and $20 \mu \mathrm{g} \mathrm{L} \mathrm{L}^{-1} \mathrm{Co}(\mathrm{II})$. Deposition of Bi-film at $-1.1 \mathrm{~V}$ for $60 \mathrm{~s}$ followed by accumulation at $-0.8 \mathrm{~V}$ for $120 \mathrm{~s}$; equilibration time of $15 \mathrm{~s}$. Inset: Corresponding calibration plot with $R^{2}$ of 0.999 and related confidence band. Other conditions as in Fig. 2.

Table 2. The relative signals obtained for $4 \mu \mathrm{gL}-1$ Ni(II) in the presence of interfering ions or compound. Deposition of $\mathrm{Bi}$ at $-1.1 \mathrm{~V}$ for $60 \mathrm{~s}$ followed by accumulation at $-0.8 \mathrm{~V}$ for $60 \mathrm{~s}$; equilibration time of 15 s. Other conditions as in Figure 2.

\begin{tabular}{lll}
\hline Interferent & Weight excess & Relative signal [a] \\
\hline $\mathrm{Zn}(\mathrm{II})$ & 100 & 1.00 \\
& 500 & 1.02 \\
$\mathrm{Fe}(\mathrm{III})$ & 100 & 1.11 \\
& 500 & 1.22 \\
$\mathrm{Al}(\mathrm{III})$ & 100 & 0.89 \\
& 500 & 0.79 \\
$\mathrm{Cu}(\mathrm{II})$ & 100 & 0.99 \\
& 500 & 0.77 \\
$\mathrm{Cr}(\mathrm{III})$ & 100 & 1.09 \\
& 500 & 1.03 \\
$\mathrm{Co}(\mathrm{II})$ & 10 & 1.00 \\
& 50 & 0.49 \\
Triton X-100 & 25 & 1.07 \\
& 250 & 0.26 \\
\hline
\end{tabular}

[a] Relative signal is the ratio between the $\mathrm{Ni}(\mathrm{II})$ peak current before and after the addition of the interfering ion or compound.

\subsection{Analysis of Certified Reference Material}

The proposed $\mathrm{Bi}-\mathrm{AuE}$ was tested for measuring $\mathrm{Ni}$ (II) and $\mathrm{Co}(\mathrm{II})$ in NIST 1640a certified reference material; $1 \mathrm{~mL}$ of NIST $1640 \mathrm{a}$ was diluted 1: 10 with $0.1 \mathrm{~mol} \mathrm{~L}^{-1}$ ammonium buffer solution, containing $0.01 \mathrm{molL}^{-1}$ sodium potassium tartrate, $1 \times 10^{-5} \mathrm{molL}^{-1} \mathrm{DMG}$, and $10 \mathrm{mg} \mathrm{L}^{-1} \mathrm{Bi}(\mathrm{III})$. The AdCSVs were characterized by two stripping signals with their peak potentials at ca. $-0.9 \mathrm{~V}$ and $-1.0 \mathrm{~V}$, which increased linearly with the additions of both $\mathrm{Ni}(\mathrm{II})$ and $\mathrm{Co}(\mathrm{II})$, respectively. The sample concentrations, calculated by extrapolation of the calibration plots shown in Figure 9, and considering the dilution factor, were $27.4 \pm 0.5 \mu \mathrm{gL}^{-1}$ for $\mathrm{Ni}$ (II) and $18.1 \pm 0.6 \mu \mathrm{gL}^{-1}$ for $\mathrm{Co}(\mathrm{II})$. These values are in satisfacto-

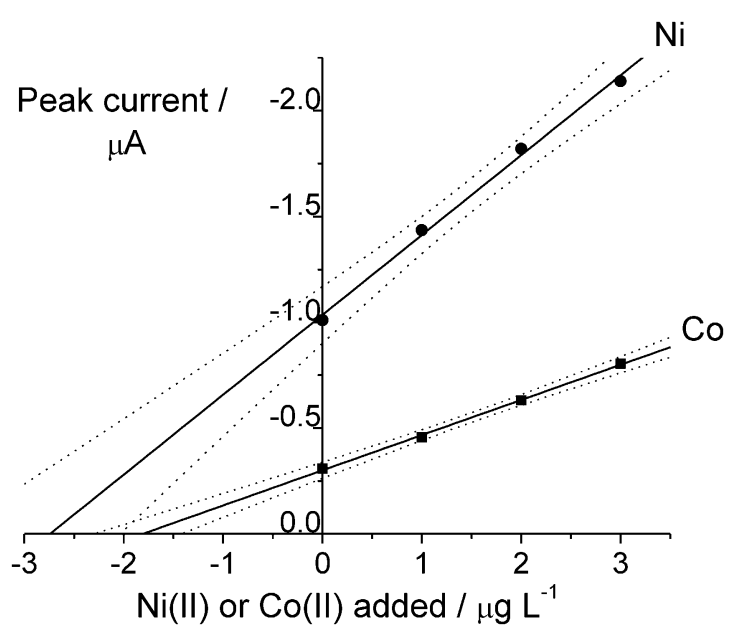

Fig. 9. Standard addition plots and relevant confidence bands $(95 \%)$ obtained at Bi-AuE for NIST 1640a certified reference sample diluted 1:10. Other conditions as in Figure 2.

ry agreement with the certified values of $27.4 \pm 0.8 \mu \mathrm{g} \mathrm{L}^{-1}$ and $20.3 \pm 0.3 \mu \mathrm{gL}^{-1}$ for this reference material.

\subsection{Real Sample Analysis}

The proposed procedure was applied for measuring $\mathrm{Ni}(\mathrm{II})$ in real water sample; the sample was collected in the Venice lagoon basin, in the area close to Murano island. After sampling, the water was filtered $(0.45 \mu \mathrm{m})$ and acidified with nitric acid $(\mathrm{pH} 2.0)$ following the standard procedure used for heavy metal analysis in water [42], before the analysis the sample was stored at $4^{\circ} \mathrm{C}$. The baseline (dashed line in Figure 10) was recorded to verify the cleanness of the glassware and purity of the reagents. Then $5 \mathrm{~mL}$ of the sample was diluted with $15 \mathrm{~mL}$ of $0.1 \mathrm{~mol} \mathrm{~L}^{-1}$ ammonia buffer solution (the dilution is 


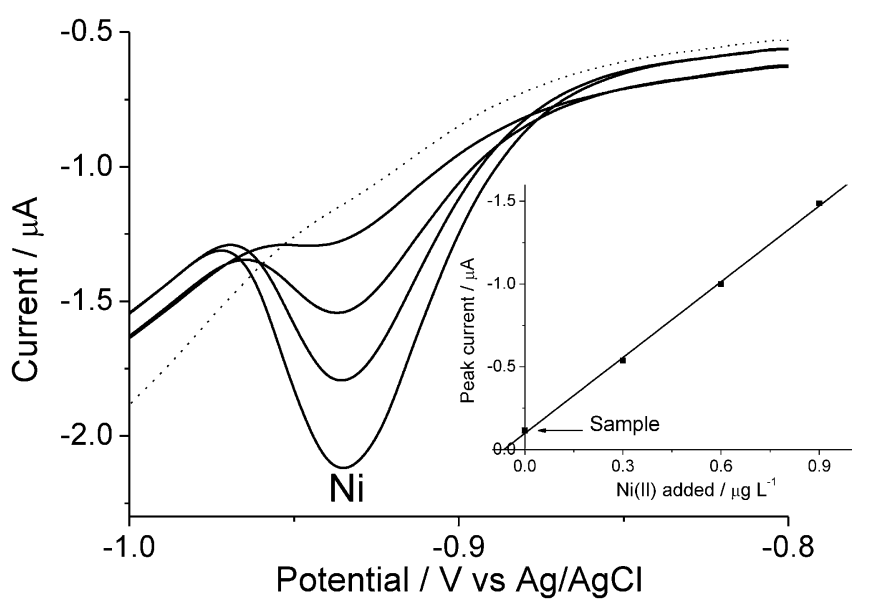

Fig. 10. AdCSVs for measuring (Ni(II) in Lagoon water sample via standard addition protocol. Conditions: deposition of Bi film at $-1.1 \mathrm{~V}$ for $60 \mathrm{~s}$ followed by accumulation at $-0.8 \mathrm{~V}$ for $240 \mathrm{~s}$. Other conditions as in Figure 2. Inset: Corresponding standard additions plot.

necessary to provide a medium $\mathrm{pH}$ of 9.0) and after an accumulation time of $240 \mathrm{~s}$, AdCSV was recorded. The concentration of $\mathrm{Ni}(\mathrm{II})$ in the real sample was calculated through the standard addition method, i.e., 3 additions of $0.3 \mu \mathrm{g} \mathrm{L}{ }^{-1} \mathrm{Ni}(\mathrm{II})$, resulting in a value of $0.41 \pm 0.17 \mu \mathrm{g} \mathrm{L}^{-1}$ $(n=3)$. The Inset of Figure 10 also demonstrates that a satisfactory linear response was achieved with a correlation coefficient $R^{2}$ of 0.998 .

Additionally, the same sample was analyzed with both ICP-OES and ICP-MS techniques in order to confirm the results obtained with the proposed electrochemical method. With ICP-OES it was not possible to determine the concentration of $\mathrm{Ni}$ (II) since it was lower than the corresponding limit of detection. On the other hand, with ICP-MS the obtained concentration of $\mathrm{Ni}$ (II) was $0.33 \pm$ $0.01 \mu \mathrm{gL}^{-1}(n=8)$ that corroborates a satisfactory agreement with the electrochemical analysis. The ICP-MS yielded also a concentration of $\mathrm{Co}$ (II) equal to $0.63 \pm$ $0.01 \mu \mathrm{gL}^{-1} \quad(n=8)$; considering the dilution needed for electrochemical analysis, this value could not be achieved with the proposed method, since it was lower than the corresponding limit of quantification.

\section{Conclusions}

The in situ preparation of bismuth-modified gold electrode allows convenient simultaneous determination of low concentration levels of $\mathrm{Ni}(\mathrm{II})$ and $\mathrm{Co}(\mathrm{II})$ in combination with adsorptive cathodic stripping voltammetry. After optimization, the developed analytical procedure turned out as a promising method with analytical results characterized by satisfactory accuracy and precision, being, at the same time, competitive with more complex and expensive analytical procedures such as ICP-MS or ICP-OES techniques. The present study also showed that the proposed method can be successfully applied for trace analysis of $\mathrm{Ni}(\mathrm{II})$ and $\mathrm{Co}(\mathrm{II})$ in natural waters; in principle, its application can be extended to monitoring a possible contamination of drinking waters and foodstuff, fulfilling the requirements indicated by recent recommendations and guidelines $[43,44]$.

\section{Acknowledgements}

This work was partially supported by MIUR-Rome (2010AXENJ8), Regione Veneto (RESMIA Project) and the Slovenian Research Agency (P1-0034).

\section{References}

[1] J. Wang, Analytical Electrochemistry, Wiley-VCH, New York 2006.

[2] M. G. Paneli, A. Voulgaropoulos, Electroanalysis 1993, 5, 355.

[3] C. M.A. Brett, A. M.C. F. Oliveira Brett, J. L.C. Pereira, Electroanalysis 1991, 3, 683.

[4] H. Li, R. B. Smart, Anal. Chim. Acta 1996, 333, 131.

[5] O. Domínguez, M. J. Arcos, Anal. Chim. Acta 2002, 470, 241.

[6] B. Baś, Anal. Chim. Acta 2006, 570, 195.

[7] R. Piech, B. Baś, W. W. Kubiak, Talanta 2008, 76, 295.

[8] V. Arancibia, C. Muñoz, Talanta 2007, 73, 546.

[9] P. Kapturski, A. Bobrowski, J. Electroanal. Chem. 2008, 617, 1.

[10] Ø. Mikkelsen, K. H. Schrøder, Electroanalysis 2001, $13,687$.

[11] M. A. Nolan, S. P. Kounaves, Anal. Chem. 1999, 71, 3567.

[12] Ø. Mikkelsen, S. M. Skogvold, K. H. Schrøder, M. I. Gjerde, T. A. Aarhaug, Anal. Bioanal. Chem. 2003, 377, 322.

[13] I. Švancara, M. Matoušek, E. Sikora, K. Schachl, K. Kalcher, K. Vytřas, Electroanalysis 1997, 9, 827.

[14] J. Wang, J. Lu, S. B. Hocevar, P. A.M. Farias, B. Ogorevc, Anal. Chem. 2000, 72, 3218.

[15] E. A. Hutton, B. Ogorevc, S. B. Hočevar, M. R. Smyth, Anal. Chim. Acta 2006, 557, 57.

[16] E. A. Hutton, S. B. Hočevar, B. Ogorevc, M. R. Smyth, Electrochem. Commun. 2003, 5, 765.

[17] J. Wang, J. M. Lu, Electrochem. Commun. 2000, 2, 390.

[18] D. Ruhlig, A. Schulte, W. Schuhmann, Electroanalysis 2006, $18,53$.

[19] L. A. Piankova, N. A. Malakhova, N. Y. Stozhko, K. Z. Brainina, A. M. Murzakaev, O. R. Timoshenkova, Electrochem. Commun. 2011, 13, 981.

[20] G. M. S. Alves, J. M. C. S. Magalhaes, H. M. V. M. Soares, Electroanalysis 2013, 25, 1247.

[21] L. Baldrianova, I. Svancara, A. Economou, S. Sotiropoulos, Anal. Chim. Acta 2006, 580, 24.

[22] I. Rutyna, M Korolczuk, Electroanalysis 2011, 23, 637.

[23] A. Mardegan, S. Dal Borgo, P. Scopece, L. M. Moretto, S. B. Hočevar, P. Ugo, Electrochem. Commun. 2012, 24, 28.

[24] X. Du, W. Gong, Y. Zhang, M. Wang, S. Wang, J.-I. Anzai, Sens. Lett. 2007, 5, 572.

[25] M. Oliveira Salles, D. Battistel, A. Silva Lima, M. Bertotti, S. Daniele, Electroanalysis 2011, 23, 595.

[26] M. Jacobsen, H. Duwensee, F. Wachholz, M. Adamovski, G.-U. Flechsig, Electroanalysis 2010, 22, 1483.

[27] P. Salaün, K. B. Gibbon-Walsh, G. M. S. Alves, H. M.V. M. Soares, C. M.G. van den Berg, Anal. Chim. Acta 2012, 746, 53. 
[28] G. M. S. Alves, J. M.C. S. Magalhães, P. Salaün, C. M. G. van den Berg, H. M.V. M. Soares, Anal. Chim. Acta 2011, 703, 1.

[29] A. Mardegan, P. Scopece, F. Lamberti, M. Meneghetti, L. M. Moretto, P. Ugo, Electroanalysis 2012, 24, 798.

[30] P. Ugo, S. Zampieri, L. M. Moretto, D. Paolucci, Anal. Chim. Acta 2001, 434, 291.

[31] M. Korolczuk, I. Rutyna, K. Tyszczuk, Electroanalysis 2010 , 22, 1494.

[32] M. Korolczuk, A. Moroziewicz, M. Grabarczyk, Anal. Bioanal. Chem. 2005, 382, 1678.

[33] H. Sopha, V. Jovanovski, S. B. Hocevar, B. Ogorevc, Electrochem. Commun. 2012, 20, 23.

[34] M. Korolczuk, K. Tyszczuk, M. Grabarczyk, Electrochem. Commun. 2005, 7, 1185.

[35] J. Pérez-Peña, J. J. Hernández-Brito, J. A. Herrera-Melián, C. Collado-Sánchez, C. M. G. van den Berg, Electroanalysis 1994, 6, 1069.

[36] E. A. Hutton, S. B. Hocevar, B. Ogorevc, Anal. Chim. Acta 2005, 537, 285.
[37] J.-M. Ouyang, H. Zeng, S.-P. Deng, J. Cryst. Growth 2006, $293,118$.

[38] S. B. Hocevar, S. Daniele, C. Bragato, B. Ogorevc, Electrochim. Acta 2007, 53, 555.

[39] A. Królicka, A. Bobrowski, Electrochem. Commun. 2004, 6, 99.

[40] F. Ma, D. Jagner, L. Renman, Anal. Chem. 1997, 69, 1782.

[41] M. Morfobos, A. Economou, A. Voulgaropoulos, Anal. Chim. Acta, 2004, 519, 57.

[42] M. Belli, D. Centioli, P. De Zorzi, U. Sansone, S. Capri, R. Pagnotta, M. Pettine, Metodi Analitici per le acque, APAT, Roma 2004, pp. 202.

[43] C. Reilly, Metal Contamination of Food, 3rd ed., Blackwell Science, New York 2005.

[44] WHO, Nickel in Drinking Water, WHO Guidelines for Drinking-water Quality, World Heath Organization, Geneva 2005. 